TECHNICIANS OF HUMAN DIGNITY 
This page intentionally left blank 
just ideas

transformative ideals of justice in ethical and political thought

series editors

Drucilla Cornell

Roger Berkowitz 
This page intentionally left blank 


\title{
TECHNICIANS OF HUMAN DIGNITY
}

\author{
BODIES, SOULS, AND THE MAKING \\ OF INTRINSIC WORTH
}

Gaymon Bennett 


\section{Copyright (C) 2016 Fordham University Press}

All rights reserved. No part of this publication may be reproduced, stored in a retrieval system, or transmitted in any form or by any means-electronic, mechanical, photocopy, recording, or any other-except for brief quotations in printed reviews, without the prior permission of the publisher.

Fordham University Press has no responsibility for the persistence or accuracy of URLs for external or third-party Internet websites referred to in this publication and does not guarantee that any content on such websites is, or will remain, accurate or appropriate.

Fordham University Press also publishes its books in a variety of electronic formats. Some content that appears in print may not be available in electronic books.

Visit us online at www.fordhampress.com.

\section{Library of Congress Cataloging-in-Publication Data}

Bennett, Gaymon (date)

Technicians of human dignity : bodies, souls, and the making of intrinsic worth / Gaymon Bennett. — First edition.

pages $\mathrm{cm}$. - (Just ideas : transformative ideals of justice in ethical and political thought)

Includes bibliographical references and index.

ISBN 978-o-8232-6777-4 (cloth : alk. paper)

I. Respect for persons. 2. Bioethics. 3. Human rights. 4. Vatican Council (2nd : 1962-1965: Basilica di San Pietro in Vaticano). Constitutio pastoralis de ecclesia in mundo huius temporis. 5. United Nations. I. Title.

BJI533.R42B46 2016

$179.7-\mathrm{dc} 23$

Printed in the United States of America

$\begin{array}{llllllll}\text { I8 } & \text { I7 } & \text { I6 } & 5 & 4 & 3 & 2 & \text { I }\end{array}$

First edition 